\title{
Early Life Blockade of 5-Hydroxytryptamine 1A Receptors Normalizes Sleep and Depression-Like Behavior in Adult Knock-Out Mice Lacking the Serotonin Transporter
}

\author{
Chloé Alexandre, ${ }^{1}$ Daniela Popa, ${ }^{1}$ Véronique Fabre, ${ }^{1}$ Saoussen Bouali, ${ }^{1}$ Patrice Venault, ${ }^{2}$ Klaus-Peter Lesch, ${ }^{3}$ \\ Michel Hamon, ${ }^{1}$ and Joëlle Adrien ${ }^{1}$ \\ ${ }^{1}$ Unité Mixte de Recherche (UMR) 677, Institut National de la Santé et de la Recherche Médicale/Université Pierre et Marie Curie, ${ }^{2}$ UMR 7593 , Centre \\ National de la Recherche Scientifique, Institut Fédératif de Recherche 70 des Neurosciences, Faculté de Médecine Pierre et Marie Curie-Site Pitié- \\ Salpêtrière, 75634 Paris Cedex 13, France, and ${ }^{3}$ Department of Psychiatry, University of Würzburg, 97080 Würzburg, Germany
}

In serotonin transporter knock-out (5-HTT-/-) mice, extracellular serotonin (5-HT) levels are markedly elevated in the brain, and rapid eye movement sleep (REMS) is enhanced compared with wild-type mice. We hypothesized that such sleep impairment at adulthood results from excessive serotonergic tone during early life. Thus, we assessed whether neonatal treatment with drugs capable of limiting the impact of 5-HT on the brain could normalize sleep patterns in 5-HTT $-1-$ mutants. We found that treatments initiated at postnatal day 5 and continued for 2 weeks with the 5-HT synthesis inhibitor para-chlorophenylalanine, or for 4 weeks with the 5-HT ${ }_{1 \mathrm{~A}}$ receptor $\left(5-\mathrm{HT}_{1 \mathrm{~A}} \mathrm{R}\right)$ antagonist $N$-[2-[4-(2-methoxyphenyl)-1-piperazinyl] ethyl]- $N$-(2-pyridinyl) cyclohexane carboxamide (WAY 100635), induced total or partial recovery of REMS, respectively, in 5-HTT-1- mutants. Early life treatment with WAY 100635 also reversed the depression-like behavior otherwise observed in these mutants. Possible adaptive changes in 5- $\mathrm{HT}_{1 \mathrm{~A}} \mathrm{R}$ after neonatal treatment with WAY 100635 were investigated by measuring $5-\mathrm{HT}_{1 \mathrm{~A}}$ binding sites and $5-\mathrm{HT}_{1 \mathrm{~A}} \mathrm{mRNA}$ in various REMS- and/or depression-related brain areas, as well as $5-\mathrm{HT}_{1 \mathrm{~A}} \mathrm{R}$-mediated hypothermia and inhibition of neuronal firing in the dorsal raphe nucleus. None of these characteristics were modified in parallel with REMS recovery, suggesting that $5-\mathrm{HT}_{1 \mathrm{~A}} \mathrm{Rs}$ involved in wild-type phenotype rescue in $5-\mathrm{HTT}-1-$ mutants are located in other brain areas or in $5-\mathrm{HT}_{1 \mathrm{~A}} \mathrm{R}$-unrelated circuits where they could be transiently expressed during development. The reversal of sleep alterations and depression-like behavior after early life blockade of 5-HT ${ }_{1 \mathrm{~A}} \mathrm{R}$ in 5 -HTT- $-1-$ mutants might open new perspectives regarding preventive care of sleep and mood disorders resulting from serotonin transporter impairments during development.

Key words: sleep; development; serotonin transporter; knock-out mice; $5-\mathrm{HT}_{1 \mathrm{~A}}$ receptors; depression; DRN neurons

\section{Introduction}

Perinatal exposure to selective serotonin reuptake inhibitors (SSRIs), the most widely used antidepressants (Owens, 2004), paradoxically causes the same sleep and behavioral alterations as those associated with depression (Benca, 2000). Indeed, children born from mothers treated with SSRIs during pregnancy develop a withdrawal syndrome (Sanz et al., 2005) with marked sleep (Nordeng et al., 2001) and behavioral (Casper et al., 2003) abnormalities. In rodents, neonatal treatment with SSRIs induces life-

Received Dec. 3, 2005; revised April 10, 2006; accepted April 10, 2006.

This work was supported by Institut National de la Santé et de la Recherche Médicale, Université Pierre et Marie Curie, and European Community (Program Newmood Contract LSHM-CT-2003-503474, FWP6). C.A. and D.P. were recipients of grants from Fondation Recherche Médicale, and S.B. was supported by a Ministére de l'Education Nationale, de la Recherche et de la Technologie fellowship during performance of these studies. Knock-out mice were generated under the support of Deutsche Forschungsgemeirschaft (SFB581). We are grateful to Dr. L. E. Schechter (Wyeth-Ayerst) for his generous gift of WAY 100635, to K. Yard for his help in behavioral tests, and to A. Herlyn for English formal corrections.

Correspondence should be addressed to Joëlle Adrien, Unité Mixte de Recherche 677, Institut National de la Santé et de la Recherche Médicale/Université Pierre et Marie Curie, Faculté de Médecine Pierre et Marie Curie, Site PitiéSalpêtrière, 91 Boulevard de l'Hôpital, 75634 Paris Cedex 13, France. E-mail: adrien@ext.jussieu.fr.

DOI:10.1523/JNEUROSCI.5156-05.2006

Copyright $\odot 2006$ Society for Neuroscience $\quad$ 0270-6474/06/265554-11\$15.00/0 long alterations of rapid eye movement sleep (REMS) (Frank and Heller, 1997), behavior (Ansorge et al., 2004), and serotonergic neurotransmission (Maudhuit et al., 1995; Maciag et al., 2005). Similarly, mutant mice that do not express the serotonin $(5-\mathrm{HT})$ transporter (5-HTT-/-), when compared with their wild-type counterparts $(5-\mathrm{HTT}+/+)$, exhibit at adulthood enhanced amounts of REMS (Wisor et al., 2003), increased anxiodepressive-like behaviors (Holmes et al., 2003; Lira et al., 2003), and altered 5-HT neurotransmission (Fabre et al., 2000a; Li et al., 2000; Gobbi et al., 2001; Bouali et al., 2003). In these mutants, such alterations may result from adaptations to the lifelong lack of 5-HTT expression, or, alternatively, from brain exposure to high levels of extracellular 5-HT (Fabre et al., 2000a; Mathews et al., 2004) at a critical period during early life (Lauder, 1990; Gaspar et al., 2003).

We hypothesized that protection of the brain from excessive 5 -HT levels in 5-HTT- - - neonates would limit the deleterious effects of the mutation on sleep expression in adults. To test this hypothesis, 5-HT synthesis was inhibited by chronic treatment with the tryptophan hydroxylase inhibitor para-chlorophenylalanine (pCPA) (Koe and Weissman, 1966) during early life, and sleep 
was examined at adulthood. Second, we focused on 5- $\mathrm{HT}_{1 \mathrm{~A}}$ receptors $\left(5-\mathrm{HT}_{1 \mathrm{~A}} \mathrm{Rs}\right)$, because of their well established involvement in the control of sleep patterns (Tissier et al., 1993; Boutrel et al., 2002; Ursin, 2002), in the effects of SSRIs on sleep (Monaca et al., 2003) and mood (Pineyro and Blier, 1999) and in brain development (Xu et al., 2004). Thus, the endogenous 5-HTdriven tonic activation of these receptors was reduced by pharmacological blockade during early life in 5-HTT $-/-$ mutants, using the selective $5-\mathrm{HT}_{1 \mathrm{~A}} \mathrm{R}$ antagonist $\mathrm{N}$-[2-[4-(2methoxyphenyl)-1-piperazinyl] ethyl]- $N$-(2-pyridinyl) cyclohexane carboxamide (WAY 100635) (Fletcher et al., 1996). Sleep patterns as well as depression-related behavior in these animals were investigated at adult stage. Finally, we searched for the central 5- $\mathrm{HT}_{1 \mathrm{~A}} \mathrm{R}$ possibly involved in the modifications observed by measuring $5-\mathrm{HT}_{1 \mathrm{~A}}$ binding sites and mRNA in selected brain areas and assessing their functional status in the dorsal raphe nucleus (DRN).

Our results indicate that brain protection from excessive serotonergic tone during early life prevents sleep alterations and depression-like behavior otherwise observed in adult mutants with impaired 5-HTT function. These rescues were not associated with parallel restoration of $5-\mathrm{HT}_{1 \mathrm{~A}} \mathrm{R}$ function in relevant brain areas, suggesting that $5-\mathrm{HT}_{1 \mathrm{~A}} \mathrm{Rs}$ involved in these phenomena are located either in other brain structures or in non-5- $\mathrm{HT}_{1 \mathrm{~A}}$ circuits in which they could be transiently expressed during development.

These findings may be of interest for developing strategies aimed at counteracting possible deleterious effects of perinatal SSRI exposure.

Parts of this paper have been published previously in abstract form (Bouali et al., 2000; Alexandre et al., 2003).

\section{Materials and Methods \\ Animals}

Animal care and experiments were conducted in accordance with the institutional guidelines, which are in compliance with national and international laws and policies (council directive 87-848, October 19, 1987, Ministère de l'Agriculture et de la Forêt, Service vétérinaire de la santé et de la protection animale, permissions $75-116$ to M.H. and 75-125 to J.A.). Mice of the 5-HTT $-/-$ and 5 -HTT $+/+$ genotypes were obtained originally from the colony of K. P. Lesch (Bengel et al., 1998) and were successively backcrossed (F7) with the Swiss albino CD-1 strain. Males and females of both genotypes used in the first series of experiments on sleep were born from both heterozygous $(n=19)$ and homozygous $(n=$ 18) breeding, whereas those used in the other series of experiments originated from homozygous breeding. Genotyping was performed using Southern blot analysis as described previously (Bengel et al., 1998).

Animals were housed in a temperature-controlled room $\left(23 \pm 1^{\circ} \mathrm{C}\right)$ under $12 \mathrm{~h}$ light/dark cycle (lights on at 7:00 A.M.), with food and water available ad libitum.

\section{Neonatal treatments}

Treatments, administered via the subcutaneous route, began on postnatal day 5 (P5; the day of birth being counted as P0) and continued for 2 weeks with the 5-HT synthesis inhibitor pCPA-methylester $(100 \mathrm{mg} / \mathrm{kg}$ dissolved in $0.05 \mathrm{ml}$ of saline; daily at 6:00 P.M.) (Dailly et al., 2006) and for 2 or 4 weeks with the $5-\mathrm{HT}_{1 \mathrm{~A}} \mathrm{R}$ antagonist WAY $100635(1 \mathrm{mg} / \mathrm{kg}$ dissolved in $0.05 \mathrm{ml}$ of saline; twice daily at 10:00 A.M. and 6:00 P.M.) (Serres et al., 2000; Boutrel et al., 2002). For each treatment, control male and female neonates received saline under the same conditions. Subsequent investigations were performed 6-12 weeks later (i.e., in 2- to 4 -month-old mice) in independent groups for studies on sleep $(n=90)$, behavior $(n=76), 5-\mathrm{HT}_{1 \mathrm{~A}} \mathrm{R}$ binding $(n=31), 5-\mathrm{HT}_{1 \mathrm{~A}} \mathrm{mRNA}(n=40)$, and electrophysiological recordings of DRN neurons $(n=31)$. For body temperature assays, mice $(n=43)$ had undergone behavioral testing at least 2 weeks before the experiment.

\section{Sleep and wakefulness analysis}

Surgery. At 2-4 months of age, animals under deep ketamine/xylazine anesthesia (100 and $10 \mathrm{mg} / \mathrm{kg}$, i.p., respectively) were implanted with electrodes (made of enameled nichrome wire; diameter, $150 \mu \mathrm{m}$ ) for polygraphic sleep monitoring (Boutrel et al., 1999; Popa et al., 2006). Briefly, two EEG electrodes were positioned onto the dura through holes made into the skull ( $2 \mathrm{~mm}$ lateral and $2 \mathrm{~mm}$ caudal to the bregma suture; $1 \mathrm{~mm}$ caudal to the lambda at midline), two electrooculogram electrodes were placed subcutaneously on each side of the orbit, and EMG electrodes were inserted into the neck muscles. All electrodes were anchored to the skull with Superbond (GACD, Paris, France) (Limoge-Lendais et al., 1994) and acrylic cement and were soldered to a miniconnector also embedded in cement. The animals were transferred to individual cages $(20 \times 20 \times 30 \mathrm{~cm})$ and were allowed to recover for $10 \mathrm{~d}$ under standard conditions (see above). They were acclimated to the recording cables for 2-3 d before recordings were started.

Scoring and analysis. Polygraphic tracings were recorded using an Embla device and the software Somnologica (Medcare, Reykjavik, Iceland) and were collected during $48 \mathrm{~h}$ for males and $96 \mathrm{~h}$ for females (Schwierin et al., 1998) (i.e., during one complete estrus cycle) (Popa et al., 2006). Recordings were scored manually every $15 \mathrm{~s}$ epoch (Lena et al., 2004) as wakefulness (W), slow wave sleep (SWS), and REMS, according to standard criteria (Boutrel et al., 2002). For analysis of basal sleep-wakefulness patterns, the total amount and the number and mean duration of episodes of each vigilance state were calculated for every hour throughout 48 and $96 \mathrm{~h}$ in males and females, respectively, and averaged over $3 \mathrm{~h}$ periods and over the entire light/dark cycle $(24 \mathrm{~h})$. The quantification of shifts from SWS to REMS over $24 \mathrm{~h}$ was made using Matlab (MathWorks, Natick, MA) routine (Lena et al., 2004).

\section{Behavioral tests}

Behavioral testing was conducted on adult mice (2-4 months of age) between 10:00 A.M. and 4:00 P.M. Each test was performed at the same hour for all groups, and most animals (70 of 76) were subjected to both locomotor activity recording followed by tail suspension test (TST), with an interval of 3-8 d between the two corresponding sessions. Experiments were performed by an observer blind to the treatment and genotype.

Locomotor activity. Mice were placed randomly and individually into a novel environment (i.e., actimeter) for $60 \mathrm{~min}$. The actimeter apparatus comprised eight individual activity cages $(30 \times 15 \times 18 \mathrm{~cm})$ with automatic monitoring of photocell beam breaks (Imetronic, Bordeaux, France) to record horizontal activity (locomotor activity).

Tail suspension test. The TST was performed using a computerized device (Bioseb, Bordeaux, France) as described previously (El Yacoubi et al., 2003). Briefly, mice were suspended by the tail with adhesive tape to a hook connected to a strain gauge. The latter transmitted movements to a computer that calculated the total duration of immobility during a $6 \mathrm{~min}$ test. Only one mouse climbed up its tail during the test session and was excluded from the study.

\section{Autoradiographic labeling of $5-H T_{1 A} R$}

Mice were killed by decapitation, and their brains were quickly removed and immediately frozen at $-30^{\circ} \mathrm{C}$ using isopentane cooled by dry ice, then stored at $-80^{\circ} \mathrm{C}$. Frontal sections $(20 \mu \mathrm{m})$ containing the hippocampus, posterior hypothalamus, DRN, and the laterodorsal tegmental nucleus (LDT) were prepared using a cryostat at $-20^{\circ} \mathrm{C}$, thawmounted serially onto gelatin-coated glass slides, and then stored at $-20^{\circ} \mathrm{C}$ until use.

Autoradiographic labeling was performed using the 5- $\mathrm{HT}_{1 \mathrm{~A}}$ antagonist radioligand $\left[{ }^{3} \mathrm{H}\right]$ WAY 100635 . Sections were preincubated at room temperature for $30 \mathrm{~min}$ in $50 \mathrm{~mm}$ Tris- $\mathrm{HCl}$ buffer, $\mathrm{pH} 7.4$, and then incubated for $1 \mathrm{~h}$ in the same buffer containing $0.8 \mathrm{nM}\left[{ }^{3} \mathrm{H}\right]$ WAY 100635 (Fabre et al., 2000a). Nonspecific binding was estimated from adjacent sections incubated in the same medium supplemented with $10 \mu \mathrm{M} 5-\mathrm{HT}$. After three $5 \mathrm{~min}$ washes in Tris- $\mathrm{HCl}$ buffer at $4^{\circ} \mathrm{C}$, the sections were rapidly dipped in ice-cold distilled water, dried in a stream of cold air, and then apposed to ${ }^{3} \mathrm{H}$-Fuji Imaging plate BAS-TR2040 (Fujifilm, Tokyo, Japan). After 3-5 d of exposure, the imaging plate was scanned using 
a phosphoimager (FLA2000; Fujifilm). The scanned image was transferred into computerized image software (Aïda 2.1; Raytest, Straubenhasdt, Germany), and optical density in each structure (Franklin and Paxinos, 1997) was measured and converted to femtomoles of $\left[{ }^{3} \mathrm{H}\right]$ WAY 100635 bound per milligram of tissue according to $\left[{ }^{3} \mathrm{H}\right]$ standards (Amersham Biosciences, Buckinghamshire, UK).

\section{Quantification of 5- $\mathrm{HT}_{1 A} \mathrm{R} m \mathrm{mNA}$}

$R N A$ preparation and first-stranded cDNA synthesis. Mice were killed by decapitation, the whole brain was removed, and the anterior raphe area and hippocampus were immediately dissected at $0-4^{\circ} \mathrm{C}$. Samples were frozen with liquid nitrogen and stored at $-80^{\circ} \mathrm{C}$ until use. Total RNA extraction was done using the Absolute RNA reverse transcription-PCR (RT-PCR) miniprep kit, according to manufacturer's instructions, including removal of genomic DNA by DNase treatment (Stratagene, La Jolla, CA). RNA integrity was checked by agarose gel electrophoresis, and RNA concentrations were determined by spectrophotometric measurements. First-stranded cDNA synthesis ( $500 \mathrm{ng}$ of total RNA per $20 \mu \mathrm{l}$ of assay mixture) was performed with SuperScript III reverse transcriptase and random primers (150 ng per reaction), as recommended by the manufacturer (Invitrogen, Cergy Pontoise, France).

Semiquantitative TaqMan PCR. PCR amplification, in triplicate for each sample, was performed using the ABI Prism 7300 apparatus (Applied Biosystems, Courtaboeuf, France) with ABgene (Courtabeuf, France) Absolute QPCR ROX mix and Assays-on-Demand Taqman probes (Applied Biosystems) for the target gene encoding $5-\mathrm{HT}_{1 \mathrm{~A}} \mathrm{R}$ and reporter genes encoding glyceraldehyde 3-phosphate dehydrogenase (GAPDH) and hypoxanthine guanine phosphoribosyltransferase (HPRT). The polymerase activation step at $95^{\circ} \mathrm{C}$ for $15 \mathrm{~min}$ was followed by 40 cycles of $15 \mathrm{~s}$ at $95^{\circ} \mathrm{C}$ and $60 \mathrm{~s}$ at $60^{\circ} \mathrm{C}$. The validity of the results was checked by running appropriate negative controls (substitution of cDNA with water at PCR amplification step or omission of reverse transcriptase at cDNA synthesis step).

Relative changes in 5- $\mathrm{HT}_{1 \mathrm{~A}}$ gene expression were analyzed using the $2^{-\Delta \Delta \mathrm{Ct}}$ method (Livak and Schmittgen, 2001) and RQ Study software (version 1.2; Applied Biosystems). All data were analyzed using GAPDH and HPRT as references.

Hypothermia induced by 8-hydroxy-2(di-n-propylamino)tetralin Core body temperature was measured at $23 \pm 1^{\circ} \mathrm{C}$ ambient temperature, with a thermocouple (diameter, $1.5 \mathrm{~mm}$; Betatherm, Galway, UK) inserted $1.5 \mathrm{~cm}$ into the rectum while gently holding the animal. Experiments began at 10:00 A.M. Basal temperature was measured $15 \mathrm{~min}$ before and just before the subcutaneous injection of saline or the $5-\mathrm{HT}_{1 \mathrm{~A}} \mathrm{R}$ agonist 8-hydroxy-2(di-n-propylamino)tetralin $(8-\mathrm{OH}-$ DPAT; 0.2 and $0.4 \mathrm{mg} / \mathrm{kg}$, dissolved in $0.1 \mathrm{ml}$ of saline) (Bouali et al., 2003; El Yacoubi et al., 2003). Temperature was recorded every $15 \mathrm{~min}$ for $1 \mathrm{~h}$ after injection and then every hour until temperature had returned to baseline value. For each animal, the hypothermic response was expressed as the difference between basal temperature and the minimal value observed during the first hour after injection.

\section{Electrophysiological activity of DRN neurons}

Mice were anesthetized with chloral hydrate $(400 \mathrm{mg} / \mathrm{kg}$, i.p.), supplemented as required to maintain optimal anesthesia throughout the experiment. Body temperature was maintained at $37-38^{\circ} \mathrm{C}$ by means of a thermostatically controlled heating blanket. Animals were positioned in a stereotaxic frame (David Kopf Instruments, Tujunga, CA), the scalp was opened, and a hole was drilled into the skull to allow subsequent vertical descent of a tungsten microelectrode (2-4 M $\Omega$ ) down to the following DRN coordinates: sagittal plane, $0.3 \mathrm{~mm}$ anterior to the lambda suture and $2.5 \mathrm{~mm}$ under the brain surface (Franklin and Paxinos, 1997). The electrical signals were fed into a high-input impedance amplifier, an oscilloscope, and an electronic rate meter triggered by individual neuronal spikes. The integrated firing rate was computed and recorded as number of spikes per $10 \mathrm{~s}$ samples.

Criteria used to identify serotonergic neurons were similar to those described previously in the mouse (i.e., long-duration biphasic action potentials and slow and regular discharge pattern) (Evrard et al., 1999; Bouali et al., 2003).
Baseline activity of each neuron was recorded during 5-10 min, after which 8-OH-DPAT was injected into the saphenous vein at the rate of one injection every 2 min until complete cessation of cell firing. To draw the dose-response curve, 8-OH-DPAT-induced decrease in neuronal firing rate was measured during the second minute after injection and expressed as percentage of baseline. Once the neuronal firing had been completely inhibited by 8 -OH-DPAT, the $5-\mathrm{HT}_{1 \mathrm{~A}}$ antagonist WAY $100635(20 \mu \mathrm{g} / \mathrm{kg})$ was injected via the same route to reverse inhibition (Evrard et al., 1999). Only one neuron per animal contributed to pharmacological data. Additional verification of DRN location of the recorded neuron was performed by electrolytically marking the recording site, followed by brain histological processing (20 $\mu \mathrm{m}$ frontal sections, cresyl violet staining) (Bouali et al., 2003).

\section{Chemicals}

The following drugs were used: 8-OH-DPAT (Research Biochemicals, Natick, MA), pCPA-methylester (Sigma, St. Louis, MO), WAY 100635 (Wyeth-Ayerst, Princeton, NJ), and [ $\left.{ }^{3} \mathrm{H}\right]$ WAY 100635 (85 Ci/mmol) (Amersham Biosciences).

\section{Statistical analyses}

All results are expressed as mean \pm SEM.

Assessing the influence of breeding. When mice were obtained from both homozygous and heterozygous breedings (in pCPA experiments), breeding pairs were compared by two-way ANOVA with factors breeding and genotype. In the other experiments, in which mice were obtained from homozygous breeding, litter means were compared by two-way ANOVA, with factors genotype and treatment.

Analysis of the sleep-wakefulness patterns. A four-way ANOVA was performed, with factors neonatal treatment (drug or saline), gender, genotype, and repeated measures over time (states of vigilance over $3 \mathrm{~h}$ segments). Additional three- or two-way ANOVAs were performed where appropriate. Significant main effects or interactions were explored by a pairwise comparison of means using the Fisher's protected least significant difference (Fisher's PLSD) post hoc test.

Behavioral tests and autoradiographic/mRNA quantifications. Results were analyzed using three-way ANOVAs with the same factors as above (treatment, gender, genotype), followed by the Fisher's PLSD test as appropriate.

Hypothermia measurements. The 8-OH-DPAT-induced hypothermia in 5 -HTT $-/-$ mice was analyzed by applying three-way ANOVA, with factors treatment, gender, and repeated measures over doses of 8-OHDPAT. In case of significance, the $F$ test was followed by the Fisher's PLSD test where appropriate.

Electrophysiological recordings. The dose-dependent inhibition of DRN neuronal firing in 5 -HTT $-/-$ mice was evaluated by three-way ANOVA, with factors neonatal treatment, gender, and repeated measures for the various doses of 8-OH-DPAT. In case of significance, a pairwise comparison of means using the Fisher's PLSD test was performed for each dose of 8-OH-DPAT, separately. Basal firing rates were analyzed using two-way ANOVA (treatment and gender) and the Fisher's PLSD test as above.

In all cases, the significance level was set at $p<0.05$.

\section{Results}

With regard to sleep parameters, no significant differences were found between mice obtained from homozygous or heterozygous breeding (ANOVA for REMS; $F_{(1,33)}=0.04 ; p=0.95$ ). In the other experiments in which all animals were derived from homozygous breeding only, the effects observed did not depend on the parental pair from which mice were born. Thus, the data for each genotype were pooled in all experiments, regardless of the breeding conditions.

\section{Sleep and wakefulness}

Sleep patterns in 5-HTT-/- and 5-HTT $+/+$ mice of the CD-1 strain

Male and female mice of both genotypes exhibited a typical lightentrained circadian rhythm of sleep and wakefulness, with more 
A
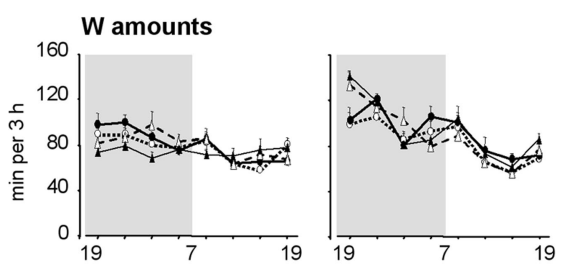

REMS amounts
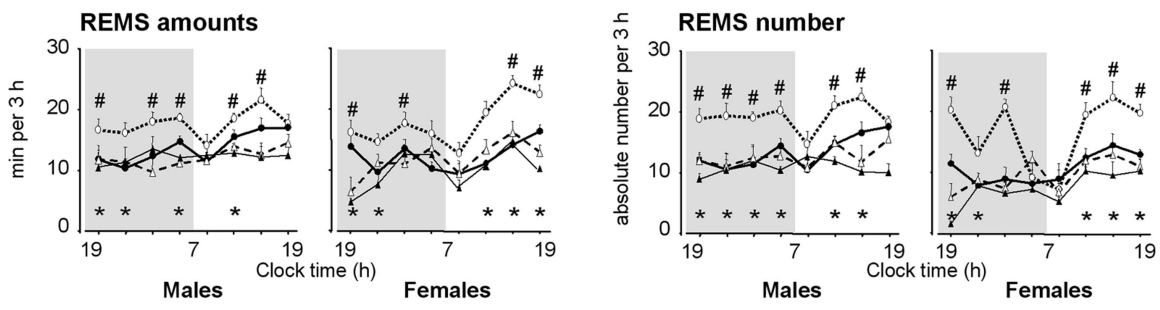

B
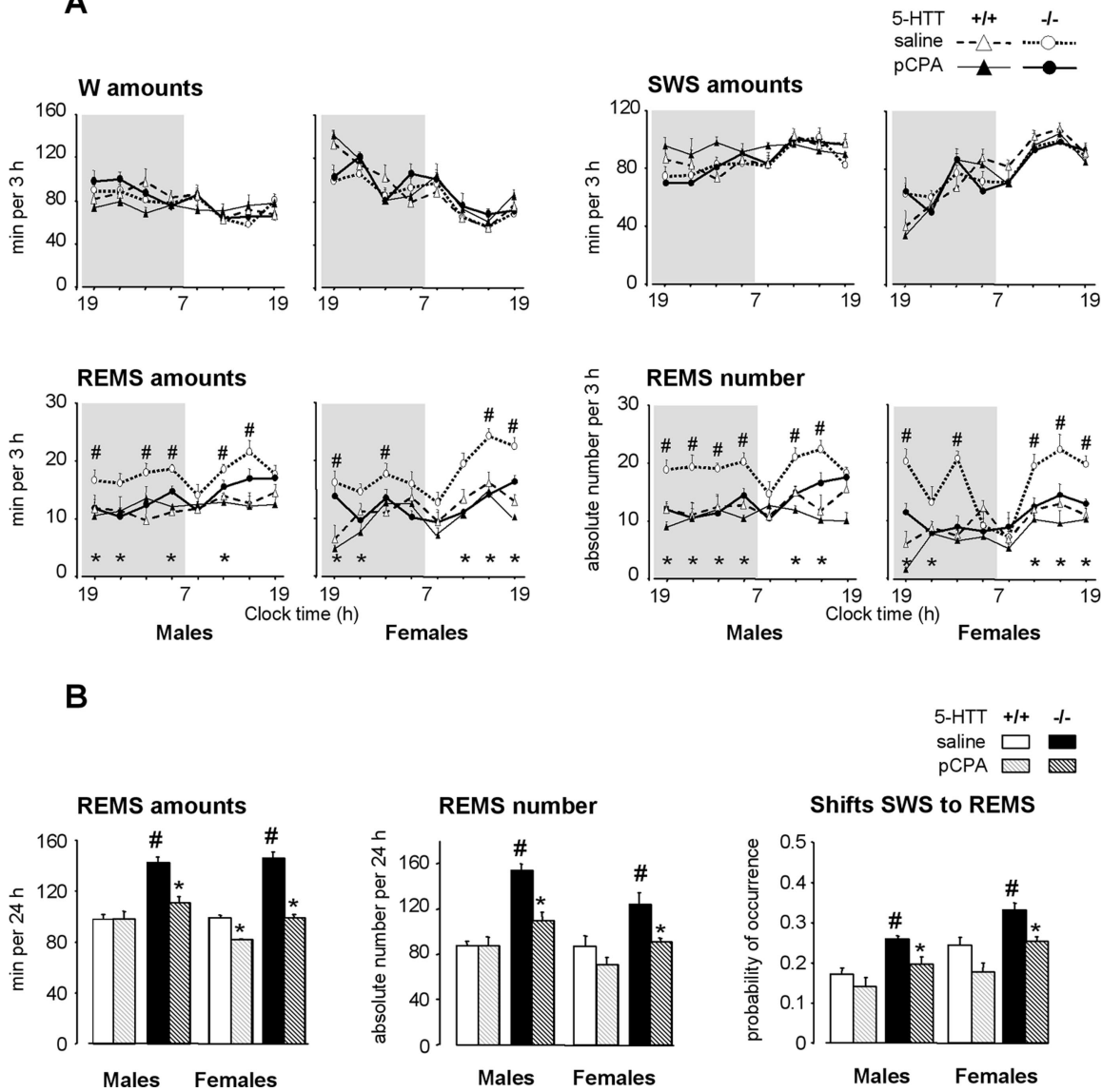

19

䧑

$p<0.0001$; REMS, $F_{(1,31)}=12.62, p=$
0.001 ) (Table 1) episodes. These results suggest that wakefulness and sleep were less fragmented in females than in males.

\section{Sleep patterns after early life inhibition of} 5-HT synthesis

Neonatal treatment with pCPA did not affect $\mathrm{W}$ and SWS, but it reduced REMS amounts throughout the entire circadian period (over $3 \mathrm{~h}$ segments; $F_{(1,217)}=44.10$; $p<0.0001$ ), with a significant genotypetreatment interaction $\left(F_{(1,217)}=18.40\right.$; $p<0.001$ ) (Fig. 1).

In both male and female 5-HTT-/mutants, pCPA treatment induced a marked decrease in REMS amounts over $24 \mathrm{~h}\left(F_{(1,20)}=57.90 ; p<0.0001\right)$ (Table 1 ), which was accompanied by a reduction in the number of episodes $\left(F_{(1,20)}=26.53\right.$; $p<0.0001$ ) (Table 1, Fig. 1). Thus, REMS parameters in 5 -HTT $-1-$ mutants treated with pCPA were similar to those of saline-treated $5-\mathrm{HTT}+/+$ mice.

In $5-\mathrm{HTT}+/+$ mice, the same neonatal treatment with pCPA induced a small decrease in REMS amounts, but only in females (gender-treatment interaction; $\left.F_{(1,17)}=5.35 ; p=0.03\right)$ (Table 1, Fig. 1).

These data suggest that the REMS enhancement observed in adult 5-HTT-1mutants results from increased 5-HT levels (Fabre et al., 2000a) during early postsleep during the light than the dark period (Figs. 1, 2). Sleepwakefulness parameters (total amounts, number, and mean duration of episodes) were similar in groups of mice treated neonatally with saline during 2 or 4 weeks. Accordingly, data from all saline-treated groups were pooled for this analysis.

Genotype-related differences. Both male and female 5-HTT $-/-$ mutants exhibited larger amounts of REMS over $24 \mathrm{~h}$ than paired 5 -HTT $+/+$ mice $\left(F_{(1,31)}=142.16 ; p<0.0001\right)$ (Table 1, Figs. 1, 2). This enhancement in 5-HTT-/- mutants was accounted for by a significant increase in the number of episodes $\left(F_{(1,31)}=52.83 ; p<0.0001\right)$, with no modification of their mean duration (data not shown) and an increase in the relative number of shifts from SWS to REMS $\left(F_{(1,31)}=39.39 ; p<\right.$ 0.0001).

There was also a small decrease of W amounts in 5-HTT-1mutants $\left(F_{(1,31)}=4.15 ; p=0.05\right)$, with significantly shorter $\left(F_{(1,31)}=26.45 ; p<0.0001\right)$ and more frequent $\left(F_{(1,31)}=20.85\right.$; $p=0.0001)$ episodes than in 5 -HTT $+/+$ mice, indicating that mutants failed to produce sustained wakefulness. SWS parameters were similar in both genotypes.

Gender-related differences. Compared with males, females spent more time in $\mathrm{W}\left(F_{(1,31)}=15.17 ; p=0.0005\right)$, less in SWS natal brain maturation. With this in mind, we examined whether this phenomenon was mediated by $5-\mathrm{HT}_{1 \mathrm{~A}} \mathrm{R}$, which are known to play a key role in REMS regulation (Boutrel et al., 2002). For this purpose, we treated 5-HTT $-/-$ mutants and $5-\mathrm{HTT}+/+$ mice during early life with a selective $5-\mathrm{HT}_{1 \mathrm{~A}} \mathrm{R}$ antagonist.

Sleep patterns after early life blockade of $5-H T_{1 A} R$

Neonatal treatment with the highly selective $5-\mathrm{HT}_{1 \mathrm{~A}} \mathrm{R}$ antagonist WAY 100635 (initiated at P5) during 2 weeks had no effect on REMS in any group of mice (Table 1 ). In contrast, neonatal treatment for 4 weeks with this drug induced a significant decrease in the amounts of REMS (over $3 \mathrm{~h}$ segments; $F_{(1,245)}=15.67 ; p<$ $0.001)$ with a genotype-treatment interaction $\left(F_{(1,245)}=7.72 ; p<\right.$ 0.01 ) (Fig. 2).

In 5 -HTT $-/-$ mutants that had been treated with WAY 100635 during 4 weeks, REMS amounts over $24 \mathrm{~h}$ were decreased $45.00 ; p<0.0001)$ (Table 1, Fig. 2). This decrease was accounted for by a reduction in the number of REMS episodes $\left(F_{(1,22)}=\right.$ $8.21 ; p<0.01)$, especially in males, and in the relative number of shifts from SWS to REMS $\left(F_{(1,22)}=25.37 ; p<0.0001\right)$. These REMS characteristics reached wild-type values in males but not in both genders compared with saline-treated controls $\left(F_{(1,22)}=\right.$ 
in females $(p=0.07$ and $p<0.0001$, respectively, compared with saline-treated 5 -HTT $+/+$ mice), indicating an incomplete REMS restoration in female 5-HTT-/- mutants.

To assess the developmental component of such restoration, we performed the same 4 week treatment with WAY 100635 during the second month of life in mice of both genotypes. No long-term modifications of sleep were observed in any genotype ( $n=3$ in each group; data not shown), suggesting that the lifelong restoration of REMS after treatment with WAY 100635 depends on the developmental period for which it was administered.

Finally, in 5-HTT $+/+$ mice, neonatal treatment with WAY 100635 affected neither REMS nor the other vigilance states (Table 1, Fig. 2).

Collectively, these data indicate that REMS, which is overexpressed in adult 5 -HTT-/ - mutants of both genders, could be permanently reduced to almost wild-type levels by preventing the endogenous 5-HT-driven activation of $5-\mathrm{HT}_{1 \mathrm{~A}} \mathrm{R}$ during the first month of postnatal life (Table 1, Fig. 2). This led us to investigate: (1) whether such early life treatment with WAY 100635 during 4 weeks induced parallel modifications of depression-like behavior in 5-HTT-/- mutants and (2) whether the structures possibly involved in these functional alterations exhibited $5-\mathrm{HT}_{1 \mathrm{~A}} \mathrm{R}$ adaptive changes.

\section{Behavior}

Because REMS enhancement has been observed in a mouse depression model obtained from selective breeding based on response to the TST (El Yacoubi et al., 2003) and 5-HTT-/- mutants exhibit in-

creased REMS as well as depression-related behavior (Lira et al., 2003), we investigated whether early life blockade of $5-\mathrm{HT}_{1 \mathrm{~A}} \mathrm{R}$ normalized this behavior, in parallel with REMS patterns.

\section{Depression-related behavior}

In the TST (Fig. 3A), immobility was of longer duration in 5 -HTT $-/-$ mutants of both genders treated with saline than in paired 5 -HTT $+/+$ mice $\left(F_{(1,68)}=6.3 ; p<0.05\right)$. Early life treatment with WAY 100635 induced a significant decrease in immobility duration in 5-HTT- $/$ - mutants of both genders $\left(F_{(1,68)}=\right.$ 5.98; $p<0.05)$, but no changes in 5 -HTT $+/+$ mice, such that mutants treated with the $5-\mathrm{HT}_{1 \mathrm{~A}} \mathrm{R}$ antagonist attained the same levels as those in wild-type mice $(p=0.74$ and $p=0.75$ in mutants compared with male and female saline-treated $5-\mathrm{HTT}+/+$ mice, respectively).

To determine the relevance of this test, we examined whether the changes in mobility were ascribed to helplessness rather than to some modifications of motor activity. Recording of locomotor activity in a novel environment showed a decrease in male and female 5-HTT $-/-$ mutants treated with saline compared with paired 5 -HTT $+/+$ mice $\left(F_{(1,61)}=53.43 ; p<0.0001\right)$ (Fig. $\left.3 B\right)$.
Early life treatment with WAY 100635 slightly increased locomotor performance in male 5 -HTT $+/+$ mice but exerted no motor effects in 5-HTT-/- mutants (Fig. 3B).

Thus, early life blockade of $5-\mathrm{HT}_{1 \mathrm{~A}} \mathrm{R}$ normalized behavior in the TST, in such a manner that neonatally treated 5-HTT-/mutants of both genders exhibited an immobility duration similar to that of 5 -HTT $+/+$ counterparts. This effect was not attributable to a general enhancement of locomotor activity.

\section{$5-\mathrm{HT}_{1 \mathrm{~A}} \mathrm{R}$ labeling and $\mathrm{mRNA}$ expression in various brain areas involved in sleep/behavior regulations}

We then explored possible adaptive changes in $5-\mathrm{HT}_{1 \mathrm{~A}} \mathrm{R}$ that might have contributed to the normalization of sleep and TST behavior in 5-HTT - / - mutants after early life blockade of these receptors.

For this purpose, we first quantified $5-\mathrm{HT}_{1 \mathrm{~A}} \mathrm{R}$ binding sites labeled with $\left[{ }^{3} \mathrm{H}\right]$ WAY 100635 in various brain areas known to be involved in sleep and/or depression-related behavior [i.e., posteroventral and posterodorsal hypothalamus, amygdala, hippocampus (CA1 field), LDT, pontine reticular formation (PRF), 
Table 1. Sleep and wakefulness characteristics during $24 \mathrm{~h}$ in male and female 5-HTT $-/-$ and 5-HTT +/ + mice treated neonatally with saline, pCPA, or WAY 100635

\begin{tabular}{|c|c|c|c|c|c|c|}
\hline & \multicolumn{2}{|l|}{ W } & \multicolumn{2}{|l|}{ SWS } & \multicolumn{2}{|l|}{ REMS } \\
\hline & males & females & males & females & males & females \\
\hline \multicolumn{7}{|l|}{ 5-HTT-/- } \\
\hline \multicolumn{7}{|l|}{ Saline 2 weeks } \\
\hline Amounts (min) & $618.8 \pm 14.4$ & $667.4 \pm 19.5$ & $679.7 \pm 11.4$ & $627.5 \pm 16.9$ & $141.5 \pm 4.5^{* *}$ & $145.0 \pm 4.6^{* *}$ \\
\hline Episodes (absolute value) & $373.9 \pm 21.8^{* *}$ & $277.0 \pm 24.1^{* * *}$ & $597.9 \pm 15.1$ & $381.6 \pm 22.1^{* * *}$ & $157.3 \pm 5.2^{* *}$ & $122.0 \pm 10.0^{* * * * * *}$ \\
\hline$n$ & 6 & 4 & 6 & 4 & 6 & 4 \\
\hline \multicolumn{7}{|l|}{ pCPA 2 weeks } \\
\hline Amounts (min) & $641.0 \pm 24.8$ & $723.2 \pm 27.1^{* * *}$ & $688.7 \pm 24.3$ & $618.2 \pm 29.6^{* * *}$ & $110.4 \pm 4.7^{*}$ & $98.0 \pm 3.1^{* *}$ \\
\hline Episodes (absolute value) & $318.2 \pm 23.2$ & $259.7 \pm 12.3^{* * *}$ & $580.8 \pm 28.4$ & $365.2 \pm 24.1^{* * *}$ & $107.9 \pm 7.0^{*}$ & $89.3 \pm 3.2^{*}$ \\
\hline$n$ & 9 & 4 & 9 & 4 & 9 & 4 \\
\hline \multicolumn{7}{|l|}{ WAY 1006352 weeks } \\
\hline Amounts (min) & $698.9 \pm 11.4^{*}$ & $716.7 \pm 62.8$ & $600.2 \pm 12.4^{*}$ & $589.3 \pm 62.3$ & $141.0 \pm 4.8$ & $134.0 \pm 3.5$ \\
\hline Episodes (absolute value) & $356.2 \pm 24.7$ & $256.2 \pm 20.9^{* * *}$ & $578.4 \pm 10.9$ & $384.5 \pm 46.7^{* * *}$ & $145.0 \pm 10.9$ & $104.6 \pm 7.6^{* * *}$ \\
\hline$n$ & 5 & 4 & 5 & 4 & 5 & 4 \\
\hline \multicolumn{7}{|l|}{ Saline 4 weeks } \\
\hline Amounts (min) & $588.1 \pm 27.5$ & $682.5 \pm 18.9^{* * *}$ & $712.8 \pm 29.1$ & $612.3 \pm 17.1^{* * *}$ & $139.1 \pm 4.3^{* *}$ & $145.2 \pm 3.3^{* *}$ \\
\hline Episodes (absolute value) & $357.3 \pm 20.6^{* *}$ & $288.7 \pm 23.6^{* *}$ & $651.2 \pm 25.7$ & $383.4 \pm 29.3^{* * *}$ & $167.7 \pm 8.1^{* *}$ & $135.1 \pm 6.2^{* * \text { ***** }}$ \\
\hline$n$ & 6 & 7 & 6 & 7 & 6 & 7 \\
\hline \multicolumn{7}{|l|}{ WAY 1006354 weeks } \\
\hline Amounts (min) & $582.0 \pm 38.1$ & $674.6 \pm 27.5^{* * *}$ & $738.8 \pm 36.1$ & $642.7 \pm 27.9^{* * *}$ & $119.3 \pm 3.4^{*}$ & $122.7 \pm 1.0^{*}$ \\
\hline Episodes (absolute value) & $377.9 \pm 21.9$ & $281.7 \pm 23.9^{* * *}$ & $661.0 \pm 42.8$ & $427.0 \pm 31.6^{* * *}$ & $134.5 \pm 13.8^{*}$ & $113.4 \pm 7.3$ \\
\hline$n$ & 6 & 7 & 6 & 7 & 6 & 7 \\
\hline \multicolumn{7}{|l|}{$5-\mathrm{HTT}+/+$} \\
\hline \multicolumn{7}{|l|}{ Saline 2 weeks } \\
\hline Amounts (min) & $637.2 \pm 20.0$ & $707.1 \pm 31.1^{* * *}$ & $705.9 \pm 29.0$ & $634.3 \pm 23.8^{* * *}$ & $96.9 \pm 4.0$ & $97.9 \pm 2.2$ \\
\hline Episodes (absolute value) & $294.5 \pm 39.1$ & $231.5 \pm 31.7^{* * *}$ & $598.4 \pm 28.0$ & $338.4 \pm 37.6^{* * *}$ & $86.0 \pm 7.9$ & $85.0 \pm 9.7^{* * *}$ \\
\hline$n$ & 4 & 4 & 4 & 4 & 4 & 4 \\
\hline \multicolumn{7}{|l|}{ pCPA 2 weeks } \\
\hline Amounts (min) & $594.1 \pm 10.7$ & $749.0 \pm 24.9^{* * *}$ & $748.6 \pm 14.1$ & $610.3 \pm 23.9^{* * *}$ & $97.3 \pm 5.7$ & $80.7 \pm 1.1^{* \text { ***** }}$ \\
\hline Episodes (absolute value) & $286.5 \pm 24.6$ & $224.0 \pm 34.8$ & $590.5 \pm 26.4$ & $253.7 \pm 23.8^{* * *}$ & $86.5 \pm 7.1$ & $69.0 \pm 7.1^{* * *}$ \\
\hline$n$ & 4 & 3 & 4 & 3 & 4 & 3 \\
\hline \multicolumn{7}{|l|}{ Saline 4 weeks } \\
\hline Amounts (min) & $667.7 \pm 32.5$ & $716.3 \pm 18.5$ & $665.3 \pm 28.1$ & $629.2 \pm 17.1$ & $106.9 \pm 7.9$ & $94.4 \pm 6.7$ \\
\hline Episodes (absolute value) & $245.5 \pm 17.5$ & $181.5 \pm 12.3^{* * *}$ & $594.2 \pm 33.7$ & $378.5 \pm 49.5^{* * *}$ & $117.2 \pm 20.1$ & $70.4 \pm 11.7^{* * *}$ \\
\hline$n$ & 4 & 4 & 4 & 4 & 4 & 4 \\
\hline \multicolumn{7}{|l|}{ WAY 1006354 weeks } \\
\hline Amounts (min) & $708.5 \pm 32.5$ & $773.8 \pm 31.7$ & $631.5 \pm 30.8$ & $572.1 \pm 28.1$ & $100.0 \pm 5.0$ & $94.1 \pm 4.9$ \\
\hline Episodes (absolute value) & $310.4 \pm 28.4$ & $194.7 \pm 37.6^{* * *}$ & $602.7 \pm 47.9$ & $263.5 \pm 38.6^{* * *}$ & $125.8 \pm 15.3$ & $74.2 \pm 6.7^{* * *}$ \\
\hline$n$ & 5 & 4 & 5 & 4 & 5 & 4 \\
\hline
\end{tabular}

The data are given as mean \pm SEM.

${ }^{*} p<0.05$, significant difference for treatment (Fisher's test); ${ }^{* *} p<0.05$, significant difference for genotype in mice treated with saline (Fisher's test); ${ }^{* * *} p<0.05$, significant difference for gender (Fisher's test).

and DRN] (Pace-Schott and Hobson, 2002; Lira et al., 2003; Gross and Hen, 2004).

In both genotypes, the density of $5-\mathrm{HT}_{1 \mathrm{~A}}$-labeled sites in the amygdala and the PRF was too low to allow reliable quantification. For the other structures examined (Fig. 4A), 5-HTT-/mutants exhibited a significantly lower density of 5- $\mathrm{HT}_{1 \mathrm{~A}} \mathrm{R}$ labeling in the hypothalamus, LDT, and DRN $(p<0.0001)$ and higher labeling in the hippocampus $\left(F_{(1,23)}=24.23 ; p<0.0001\right)$ than paired 5 -HTT $+/+$ mice, with no gender-related differences.

After neonatal blockade of $5-\mathrm{HT}_{1 \mathrm{~A}} \mathrm{R}$, the labeling of 5-HT $\mathrm{T}_{1 \mathrm{~A}}$ binding sites by $\left[{ }^{3} \mathrm{H}\right]$ WAY 100635 in 5 -HTT $-/-$ mutants was unchanged in all the structures examined, except the DRN, where increased labeling was noted in both males and females (genotypetreatment interaction; $\left.F_{(1,23)}=6.05 ; p<0.05\right)$. However, $5-\mathrm{HT}_{1 \mathrm{~A}} \mathrm{R}$ labeling in the DRN of WAY 100635-treated 5-HTT-/- mutants did not reach that of saline-treated 5 -HTT $+/+$ mice $(p<0.0001$ and $p<0.001$ compared with male and female saline-treated 5 -HTT $+/+$ mice, respectively), indicating an only partial restoration in 5 -HTT $-/-$ mutants.

In contrast, in $5-\mathrm{HTT}+/+$ mice, neonatal treatment with WAY 100635 did not induce any modifications of 5- $\mathrm{HT}_{1 \mathrm{~A}} \mathrm{R}$ labeling in all the structures examined.
We then investigated whether the changes in $5-\mathrm{HT}_{1 \mathrm{~A}} \mathrm{R}$ labeling in the DRN of early life-treated 5 -HTT $-/-$ mutants were attributable to modifications in receptor expression. As shown in Figure $4 B$, real-time semiquantitative RT-PCR determinations yielded no significant genotype- and/or treatment-related changes of 5- $\mathrm{HT}_{1 \mathrm{~A}}$ mRNA levels in the anterior raphe area, except for a slight non significant increase $(+22 \%)$ in female 5 -HTT $-/-$ mutants that had received neonatal WAY 100635, compared with paired saline-treated controls.

Conversely, parallel measurements in the hippocampus showed a marked increase in 5- $\mathrm{HT}_{1 \mathrm{~A}} \mathrm{mRNA}$ levels in 5 -HTT $-/-$ mutants compared with wild-type mice $\left(F_{(1,30)}=\right.$ 141.12; $p<0.0001$ ) (Fig. $4 B$ ). This difference between mutant and wild-type animals was as pronounced in females as in males and was unaltered by neonatal treatment with WAY 100635 $\left(F_{(1,30)}=2.93 ; p=0.10\right)$.

These results indicate that early life blockade of $5-\mathrm{HT}_{1 \mathrm{~A}} \mathrm{R}$ in 5 -HTT $-/-$ mutants only induced partial normalization of $5-\mathrm{HT}_{1 \mathrm{~A}}$ binding sites (and to some extent, of mRNA expression) in the DRN. Therefore, we performed additional investigations aimed at assessing whether the functional characteristics of $5-\mathrm{HT}_{1 \mathrm{~A}} \mathrm{R}$ in the DRN were also restored in 5-HTT-/- mutants after early life treatment with WAY 100635. 
A

\section{Tail suspension test}

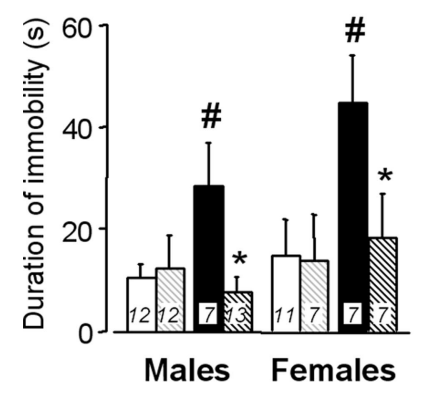

$\begin{array}{rcc}\text { 5-HTT } & +/+ & -/- \\ \text { saline } & \square & \\ \text { WAY } 100635 & \square\end{array}$

Figure 3. Effects of a 4 week neonatal treatment with WAY 100635 on behavior in the tail suspension test $(\boldsymbol{A})$ and on locomotor activity in a novel environment $(\boldsymbol{B})$, in male (left) and female (right) 5 -HTT $-/-$ (black bars) and $5 \mathrm{HTT}+/+$ (grey bars) mice treated with saline (solid bars) or WAY 100635 (hatched bars). Data are expressed as means \pm SEM for the number of animals indicated in bars. ${ }^{*} p<0.05$, significant difference for treatment (Fisher's test). ${ }^{\#} p<0.05$, significant difference for genotype in mice treated with saline (Fisher's test).

Functional status of $5-\mathrm{HT}_{1 \mathrm{~A}} \mathrm{R}$ in the DRN of 5 -HTT $-/-$ mutants: effect of early life blockade by WAY 100635

$5-\mathrm{HT}_{1 \mathrm{~A}} \mathrm{R}$ in the DRN act as somato-dendritic autoreceptors (Pineyro and Blier, 1999). Here, their functional status was assessed by two validated methods, 8-OH-DPAT-induced hypothermia (Martin et al., 1992; Li et al., 1999; Bouali et al., 2003) and inhibition of neuronal firing in the DRN (Pineyro and Blier, 1999; Gobbi et al., 2001; Bouali et al., 2003).

Core temperature response to 8-OH-DPAT

Neonatal treatment with WAY 100635 made 5-HTT-/- mice more responsive to the hypothermic effect of 8 -OH-DPAT $(0.2$ and $0.4 \mathrm{mg} / \mathrm{kg}$, s.c.), with a significant interaction between gender and treatment $\left(F_{(1,26)}=6.00 ; p<0.05\right)$. Indeed, this change reached significance only in females (Fig. 5). However, even in this group, the hypothermia response remained mostly blunted compared with that evoked by $8-\mathrm{OH}-\mathrm{DPAT}$ in paired salinetreated 5 -HTT $+/+$ females $(p<0.0001)$.

Electrophysiological response of DRN neurons to 8-OH-DPAT Whereas neonatal treatment with WAY 100635 did not modify the spontaneous firing rate of serotonergic neurons in the DRN of 5 -HTT $-/-$ mutants $(1.3 \pm 0.2$ and $1.0 \pm 0.2$ compared with $1.2 \pm 0.3$ and $1.2 \pm 0.2$ spikes per second, in males and females, respectively), it produced marked changes in the dose-dependent inhibition by $8-\mathrm{OH}-\mathrm{DPAT}$, in a gender-dependent manner, with a significant interaction between dose, gender, and treatment $\left(F_{(1,114)}=2.77 ; p<0.05\right)$ (Fig. 6).

In 5-HTT $-/-$ males, the firing response of DRN neurons to 8-OH-DPAT was not statistically different between those receiving neonatal treatment with WAY 100635 versus saline $\left(F_{(1,9)}=\right.$ $0.53 ; p=0.48)$. In contrast, in 5 -HTT $-/-$ females, the potency of 8-OH-DPAT to inhibit DRN neuronal firing was markedly enhanced after early life treatment with WAY $100635\left(F_{(1,10)}=\right.$ 16.29; $p<0.05$ ), suggesting restoration of $5-\mathrm{HT}_{1 \mathrm{~A}}$ autoreceptor sensitivity. However, this restored inhibitory response to $8-\mathrm{OH}-$ DPAT was incomplete, because it remained smaller than in saline-treated 5 -HTT $+/+$ females $(p<0.001)$.
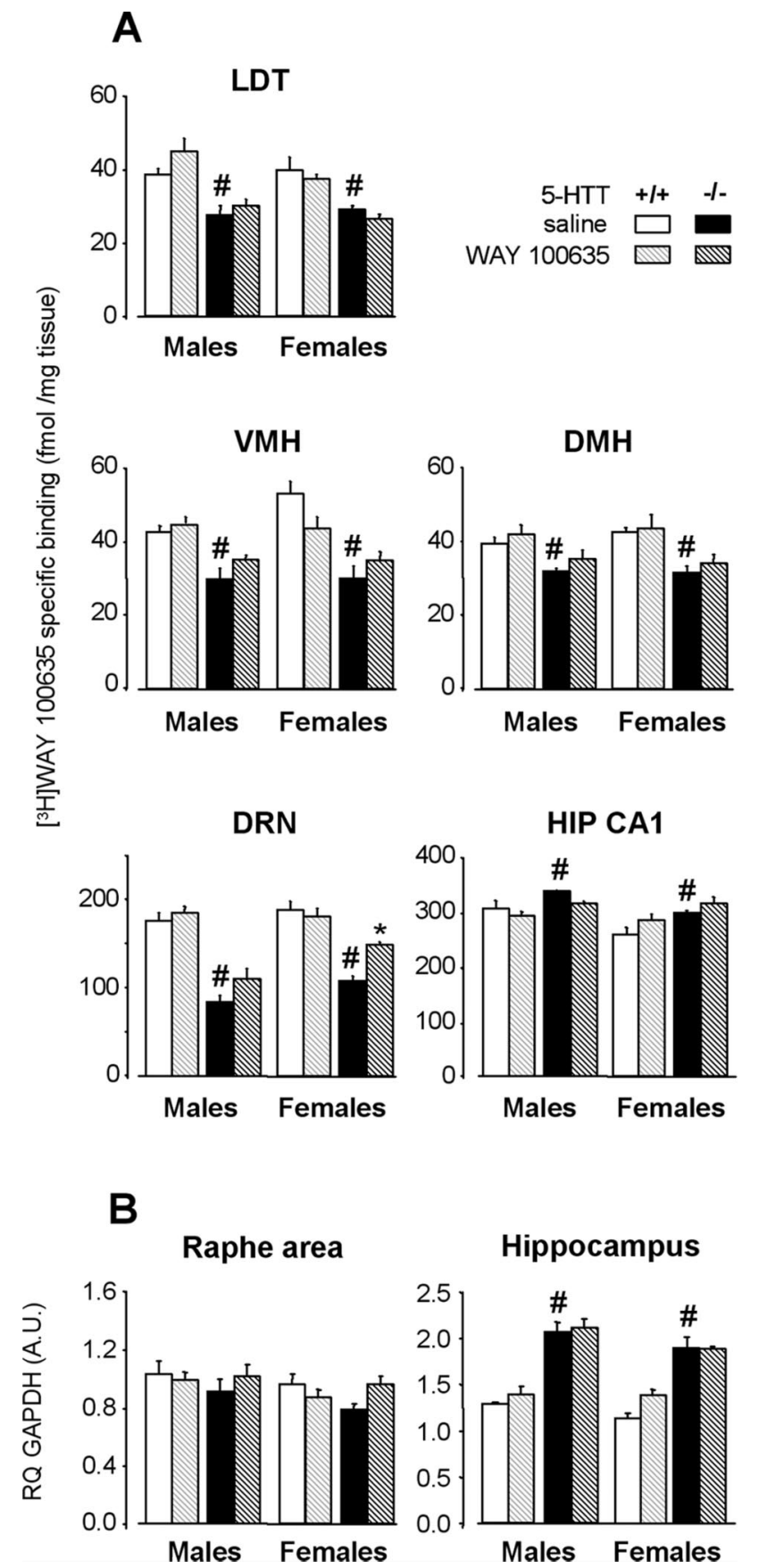

Figure 4. $\quad 5-\mathrm{HT}_{1 \mathrm{~A}} \mathrm{R}$ labeling and mRNA levels after a 4 week neonatal treatment with WAY 100635 (hatched bars) or saline (solid bars) in male (left) and female (right) 5-HTT - / - (black bars) and $5-\mathrm{HTT}+/+$ (grey bars) mice. $A$, Quantitative autoradiography of $5-\mathrm{HT}_{1 \mathrm{~A}} \mathrm{R}$ labeling by $\left[{ }^{3} \mathrm{H}\right]$ WAY 100635 in various brain areas. Data (mean \pm SEM of 3-4 animals per group) are expressed as femtomoles per milligram of tissue. $B, 5-H_{1 A} R$ mRNA levels in the anterior raphe area and the hippocampus. Results [relative quantity (RQ); mean \pm SEM of 4-5 animals per group] are expressed as arbitrary units (A.U.) after normalization to an endogenous reference gene (GAPDH). Normalization with HPRT endogenous gene (see Materials and Methods) yielded similar results. LDT, Laterodorsal tegmental nucleus; VMH, ventromedial nucleus of hypothalamus; DMH, dorsomedial nucleus of hypothalamus; HIP CA1, field of hippocampus. ${ }^{*} p<0.05$, significant difference for treatment (Fisher's test). ${ }^{\#} p<0.05$, significant difference for genotype in mice treated with saline (Fisher's test).

Thus, the (partial) recovery of body temperature and neuronal firing responses to 8-OH-DPAT challenge in 5-HTT-/mutants after early life treatment with WAY 100635 was observed in females only, indicating that the functional status of $5-\mathrm{HT}_{1 \mathrm{~A}}$ 


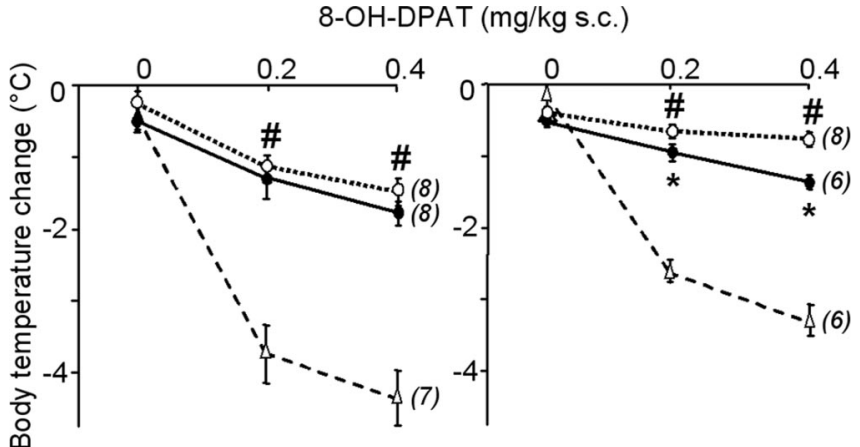

Males

\section{Females}

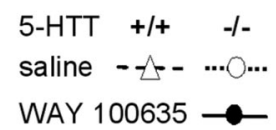

Figure 5. Dose-dependent 8-OH-DPAT-induced hypothermia in male (left) and female (right) 5-HTT-/ - mutant mice after early life treatment with saline (open symbols, dotted lines) or WAY 100635 (filled symbols, solid lines). Core body temperature changes (mean \pm SEM for the number of animals indicated in parentheses), expressed as degrees (elsius, are the difference between baseline and the lowest temperature recorded within $60 \mathrm{~min}$ after subcutaneous injection of saline ( 0 on abscissa) or $8-0 \mathrm{OH}-\mathrm{DPAT}(0.2$ and $0.4 \mathrm{mg} / \mathrm{kg}) .{ }^{*} p<0.05$, significant difference for treatment (Fisher's test). For reference data, 8-OH-DPAT-induced hypothermia was also measured in groups of paired wild-type mice that had received neonatal treatment with saline (open triangles, dashed lines). ${ }^{\#} p<0.05$, significant difference for genotype in mice treated with saline (Fisher's test).

autoreceptors in the DRN is unrelated to both gender normalization of sleep and TST behavior in 5-HTT $-/-$ mutants after early life treatment with WAY 100635.

\section{Discussion}

Our results demonstrate that abnormalities of sleep patterns, depression-related behavior, and $5-\mathrm{HT}_{1 \mathrm{~A}} \mathrm{R}$ binding in the $\mathrm{DRN}$, in male and female 5-HTT-/- mutant mice, can be durably reversed by preventing excessive $5-\mathrm{HT}_{1 \mathrm{~A}} \mathrm{R}$ stimulation by endogenous 5-HT in the CNS during early life.

\section{Sleep, behavior, and 5- $\mathrm{HT}_{1 \mathrm{~A}} \mathrm{Rs}$ are altered in}

\section{5-HTT-/- mutants}

In mice of the CD-1 strain, 5-HTT-/- mutants of both genders exhibited higher levels of REMS and enhanced depression-like behavior compared with 5 -HTT $+/+$ mice. These results confirm and extend previous data on sleep (Wisor et al., 2003) and are globally consistent with behavioral data already reported in the literature, although discrepancies exist, depending on the behavioral tests and mouse genetic background selected for relevant studies (Holmes et al., 2002; Lira et al., 2003; Ansorge et al., 2004). Interestingly, both the REMS increase and TST helpless-like behavior in 5-HTT-/- mutants closely resemble the changes seen in a murine model of depression obtained by selective breeding (El Yacoubi et al., 2003; Popa et al., 2006), supporting the idea that 5-HTT-/ - mice might represent a model of increased vulnerability to affective disorders (Holmes et al., 2003; Lira et al., 2003).

In parallel to these sleep and behavior anomalies, 5-HTT-/mutants exhibited decreased $5-\mathrm{HT}_{1 \mathrm{~A}} \mathrm{R}$ labeling in several brain areas that are involved in sleep and/or depressive-like behaviors (Pace-Schott and Hobson, 2002; Lira et al., 2003; Celada et al., 2004), except for the hippocampus, where this labeling was enhanced. These results confirm those of previous studies in 5 -HTT $-/-$ mutants of various genetic backgrounds (Fabre et
A

B
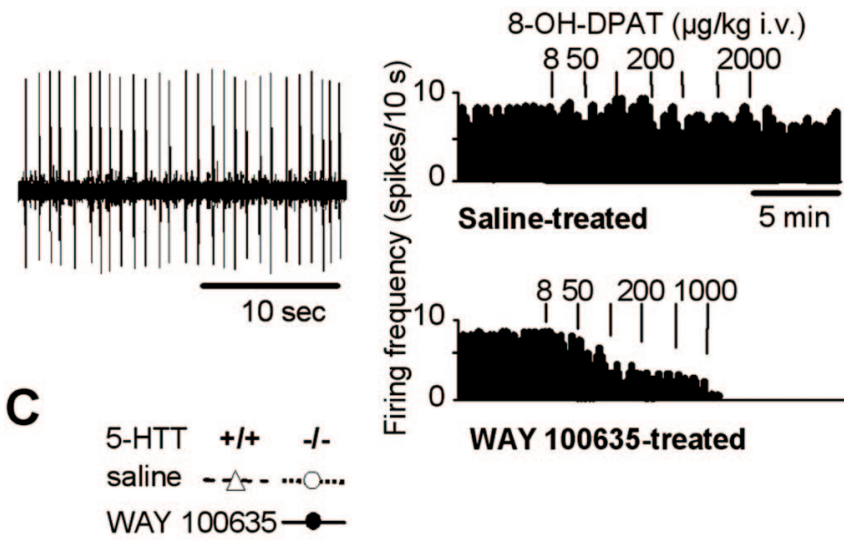

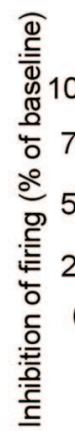
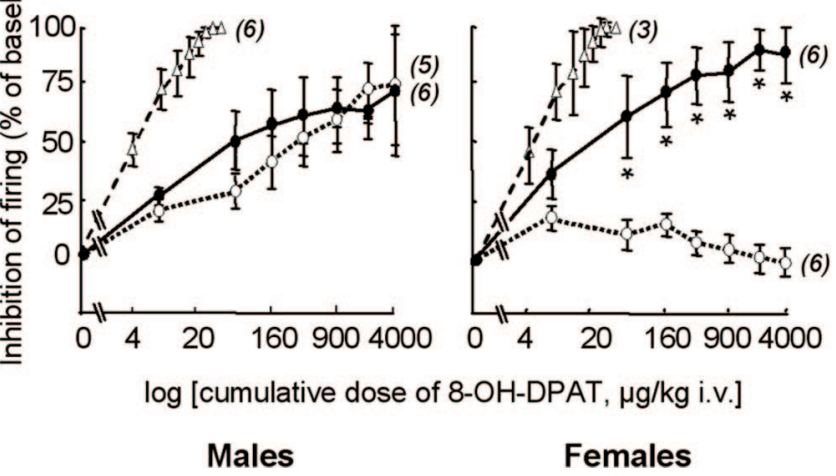

Figure 6. Functional status of $5-\mathrm{HT}_{1 \mathrm{~A}}$ autoreceptors in the DRN. $A$, Oscilloscope trace showing spontaneous firing activity of a 5-HT neuron recorded in the DRN of a wild-type female mouse. $\boldsymbol{B}$, Examples of integrated firing rate (in spikes per $10 \mathrm{~s}$ ) histograms from female 5-HTT - / - mutants treated neonatally with saline (top) or WAY 100635 (bottom). Vertical bars above histograms represent injections of 8-OH-DPAT at the dose indicated (in $\mu \mathrm{g} / \mathrm{kg}$, i.v.). C, Dose-dependent inhibition by 8-OH-DPAT of DRN neuron firing in male (left) and female (right) 5-HTT - / - mutant mice after neonatal treatment with saline (open symbols, dotted lines) or WAY 100635 (filled symbols, solid lines). Inhibition of neuron firing (mean \pm SEM of the number of neurons indicated in parentheses) is expressed as a percentage of baseline. Firing frequency was measured during the second minute after intravenous injection of cumulative doses of 8-OH-DPAT (on abscissa). The estrous cycle was not monitored because it does not influence this neuronal response (Bouali et al., 2003). ${ }^{*} p<0.05$, significant difference for treatment (Fisher's test). For reference data, 8-OH-DPAT-induced inhibition of neuronal firing was also assessed in groups of paired wild-type mice that had received neonatal treatment with saline (open triangles, dashed lines).

al., 2000a; Li et al., 2000; Gobbi et al., 2001; Bouali et al., 2003). However, increased levels of $5-\mathrm{HT}_{1 \mathrm{~A}} \mathrm{R}$ mRNA in the hippocampus with no change in the DRN contrast with previous data obtained in 5-HTT - / - mutants of the same (CD-1) (Li et al., 2000) or another (C57BL/6J) (Fabre et al., 2000a) strain of mice. This discrepancy might be ascribed to the use of different techniques to measure $5-\mathrm{HT}_{1 \mathrm{~A}}$ mRNA and also to the fact that only in our study, mice did receive repeated saline treatment during early life (which causes neonatal stress) (Holmes et al., 2005).

Nevertheless, the present data strongly suggest the existence of a link between 5-HTT loss-of-function and alterations of sleep, behavior in the TST, and $5-\mathrm{HT}_{1 \mathrm{~A}} \mathrm{R}$ expression and/or function.

REMS impairments and TST behavior in adult 5-HTT $-/-$ mutants depend on $5-\mathrm{HT}_{1 \mathrm{~A}} \mathrm{R}$ activation during early life In 5 -HTT $-/-$ mutants, early life treatment aimed at reducing either 5-HT synthesis (with pCPA) or excessive $5-\mathrm{HT}_{1 \mathrm{~A}} \mathrm{R}$ stimu- 
lation by endogenous 5-HT (with the selective antagonist WAY 100635) induced, respectively, suppression or limitation of the REMS changes normally expressed by these mutants. This suggests that REMS overexpression in adult 5-HTT-/- mutants results from excessive levels of extracellular 5-HT in the brain (Fabre et al., 2000a; Mathews et al., 2004) during development, as in the case of abnormal somatosensory cortex formation in 5-HTT - / - and monoamine oxidase A - / - mice (Gaspar et al., 2003). Indeed, REMS and behavioral alterations comparable with those in 5-HTT-/ - mutants can be mimicked in wild-type animals by neonatal augmentation of extracellular 5-HT (Vogel et al., 1990; Frank et al., 1997; Ansorge et al., 2004). These data support the hypothesis that the neonatal period (approximately the first postnatal month) is critical for the plastic/trophic role of 5-HT in sleep/behavior/brain development (Frank et al., 1997; Hansen and Mikkelsen, 1998; Ansorge et al., 2004; Morrison et al., 2005) and for the establishment of the 5-HTT-/- knock-out phenotype (Gross and Hen, 2004).

Among the 5-HT receptor types possibly mediating the normalization of sleep patterns in 5 -HTT $-/-$ mutants after early life treatment with pCPA, 5- $\mathrm{HT}_{1 \mathrm{~A}} \mathrm{R}$ demonstrated potential importance attributable to their role in sleep regulation (Tissier et al., 1993; Boutrel et al., 2002; Monaca et al., 2003) and behavior (Overstreet et al., 2003) in adulthood, and also during development, in the formation of mature neuronal circuits (Lauder, 1990; Gaspar et al., 2003) and behavior (Gross et al., 2002).

Both REMS levels and TST behavior in mutants were restored toward wild-type levels after neonatal treatment with WAY 100635. The rescue of REMS was observed after a 4 week but not 2 week treatment, a difference in efficacy that might be ascribed to the cumulative doses and/or periods of treatment. Along this line, our study supports that impairments of REMS in 5 -HTT $-/-$ mutants are attributable to $5-\mathrm{HT}_{1 \mathrm{~A}} \mathrm{R}$-mediated action of 5-HT in the brain during the first, but not the second, month of life, in agreement with other studies (Feng et al., 2001; Gross et al., 2002). Interestingly, early life treatment with WAY 100635 during 4 weeks was not as efficient as that with pCPA (administered during 2 weeks) (Table 1). This difference might be explained by the persistence of residual 5- $\mathrm{HT}_{1 \mathrm{~A}} \mathrm{R}$ activation to a higher level during treatment with WAY 100635 compared with pCPA. However, at the dose used, WAY 100635 exerts marked effects during several hours (Monaca et al., 2003) and is sufficient to protect 5- $\mathrm{HT}_{1 \mathrm{~A}} \mathrm{R}$ from SSRI-induced desensitization (Serres et al., 2000). Thus, the larger normalization observed after pCPA than after WAY 100635 could more likely result from involvement of additional 5-HT receptor types such as the 5- $\mathrm{HT}_{1 \mathrm{~B}}$ (Boutrel et al., 1999) and/or the 5- $\mathrm{HT}_{2 \mathrm{C}}$ (Amici et al., 2004).

As regards behavior, early life treatment with WAY 100635 in 5 -HTT $-/-$ mutants completely normalized the time of immobility in the TST, an effect specific to this test because global locomotor activity was unchanged by this treatment. Nevertheless, additional experiments using other depression-related challenges (Holmes et al., 2002; Lira et al., 2003) are required for assessing the efficacy of such early life treatment in reversing other depression-like behaviors and possibly in limiting vulnerability to this pathology. In addition, preliminary data (data not shown) suggest that anxiety-like behavior in the elevated plus maze after neonatal blockade of $5-\mathrm{HT}_{1 \mathrm{~A}} \mathrm{R}$ was unchanged in 5 -HTT - / - mutants. Confirmation of these results would support the hypothesis of the existence of a privileged link between depression and REMS patterns (Benca, 2000; Adrien 2002).

\section{Rescue of REMS in 5-HTT-/- mutants cannot be ascribed to central 5-HT ${ }_{1 \mathrm{~A}} \mathrm{R}$ modifications in relevant brain structures examined in adulthood}

REMS appears to be under tonic inhibitory control by 5-HT through essentially postsynaptic $5-\mathrm{HT}_{1 \mathrm{~A}} \mathrm{R}$ (Tissier et al., 1993), possibly located in the LDT or posterolateral hypothalamus (Horner et al., 1997; Muraki et al., 2004). Unexpectedly, autoradiographic labeling of $5-\mathrm{HT}_{1 \mathrm{~A}} \mathrm{R}$ in these areas, as well as in other brain structures known to be involved in REMS regulation (PaceSchott and Hobson, 2002), was unchanged after neonatal treatment with WAY 100635, which restored REMS in 5-HTT-/mutants toward wild-type levels. Similarly, no changes in $5-\mathrm{HT}_{1 \mathrm{~A}} \mathrm{R}$ labeling/expression paralleling improvement of behavior in the TST were found in structures related to helpless behavior (i.e., the hippocampus and the DRN) (Martin et al., 1990; Naudon et al., 2002; El Yacoubi et al., 2003). Interestingly, however, functional 5- $\mathrm{HT}_{1 \mathrm{~A}} \mathrm{R}$ rescue in the DRN occurred in females, but not in males. This finding is in line with previous data showing that adaptive changes affecting $5-\mathrm{HT}_{1 \mathrm{~A}}$ autoreceptors are larger in females than in males when the 5-HTT is impaired (Bouali et al., 2003; El Yacoubi et al., 2003), a phenomenon that might be related to the higher incidence of depression and related sleep disorders in women than in men.

Finally, because $5-\mathrm{HT}_{1 \mathrm{~A}} \mathrm{Rs}$ were not modified in relevant brain areas of adult 5 -HTT $-/-$ mutants after neonatal treatment with WAY 100635, it might be proposed that the mechanisms underlying REMS and TST behavior rescue would involve a strictly developmental role of $5-\mathrm{HT}_{1 \mathrm{~A}} \mathrm{R}$ (Fricker et al., 2005) interacting with other systems, such as the cholinergic system. Indeed, cholinergic neurons in the LDT and pedunculopontine nucleus, which are involved in REMS expression, were shown to develop their cholinergic phenotype during the second postnatal week and to mature functionally thereafter (Kobayashi et al., 2003; Ninomiya et al., 2005). Such maturation might be under $5-\mathrm{HT}_{1 \mathrm{~A}} \mathrm{R}$-mediated control, as in the case of neurons in the prefrontal cortex (Beique et al., 2004). Furthermore, the rescue phenomena observed here could also depend on some developmental interactions between $5-\mathrm{HT}_{1 \mathrm{~A}} \mathrm{R}$ and other 5-HT receptors, notably 5- $\mathrm{HT}_{2 \mathrm{~A}} \mathrm{R}$ (Beique et al., 2004; Celada et al., 2004). Alternatively, they might concern circuits in which $5-\mathrm{HT}_{1 \mathrm{~A}} \mathrm{R}$ would be transiently expressed during early life only (Daval et al., 1987; Gaspar et al., 2003; Patel and Zhou, 2005), where their activation could stimulate mitogen-activated protein kinase-signaling pathways, thereby producing possible neuroplastic changes (Raymond et al., 1999). Tissue-specific conditional knock-out (Gross et al., 2002) or antisense (Fabre et al., 2000b) technologies, as well as ontogenetic studies of $5-\mathrm{HT}_{1 \mathrm{~A}} \mathrm{R}$, might help to answer to this question.

In conclusion, limitation of the $5-\mathrm{HT}_{1 \mathrm{~A}} \mathrm{R}$-mediated impact of 5-HT in brain during early life prevents sleep alterations and helpless behavior that would otherwise appear in adult mice with impaired 5-HTT function. The mechanisms underlying such rescue involve a probable developmental role of $5-\mathrm{HT}_{1 \mathrm{~A}} \mathrm{R}$.

These findings may be of clinical interest regarding negative effects on sleep and emotional behavior that may occur later in life after SSRI exposure at the fetal stage.

\section{References}

Adrien J (2002) Neurobiological bases for the relation between sleep and depression. Sleep Med Rev 6:351-352.

Alexandre C, Popa D, Bouali S, Léna C, Hamon M, Adrien J (2003) Inhibition of serotonin synthesis during development restores normal REM sleep level in 5-HT transporter knock-out mice. Sleep [Abstr Suppl] 26: 0071A. 
Amici R, Sanford LD, Kearney K, McInerney B, Ross RJ, Horner RL, Morrison AR (2004) A serotonergic (5-HT2) receptor mechanism in the laterodorsal tegmental nucleus participates in regulating the pattern of rapid-eye-movement sleep occurrence in the rat. Brain Res 996:9-18.

Ansorge MS, Zhou M, Lira A, Hen R, Gingrich JA (2004) Early-life blockade of the 5-HT transporter alters emotional behavior in adult mice. Science 306:879-881.

Beique JC, Campbell B, Perring P, Hamblin MW, Walker P, Mladenovic L, Andrade R (2004) Serotonergic regulation of membrane potential in developing rat prefrontal cortex: coordinated expression of 5-hydroxytryptamine $(5-\mathrm{HT})_{1 \mathrm{~A}}, 5-\mathrm{HT}_{2 \mathrm{~A}}$, and $5-\mathrm{HT}_{7}$ receptors. J Neurosci 24:4807-4817.

Benca RM (2000) Mood disorders. In: Principles and practice of sleep medicine (Kryger M, Roth T, Dement W, eds), pp 1140-1158. Philadelphia: Saunders.

Bengel D, Murphy DL, Andrews AM, Wichems CH, Feltner D, Heils A, Mossner R, Westphal H, Lesch KP (1998) Altered brain serotonin homeostasis and locomotor insensitivity to 3,4-methylenedioxymethamphetamine ("Ecstasy") in serotonin transporter-deficient mice. Mol Pharmacol 53:649-655.

Bouali S, Evrard A, Hamon M, Adrien J (2000) Impairment of central serotonin metabolism during development results in permanent modifications of 5- $\mathrm{HT}_{1 \mathrm{~A}}$ autoreceptor sensitivity in mice. Soc Neurosci Abstr 26: 144.6.

Bouali S, Evrard A, Chastanet M, Lesch KP, Hamon M, Adrien J (2003) Sex hormone-dependent desensitization of $5-\mathrm{HT}_{1 \mathrm{~A}}$ autoreceptors in knockout mice deficient in the 5-HT transporter. Eur J Neurosci 18:2203-2212.

Boutrel B, Franc B, Hen R, Hamon M, Adrien J (1999) Key role of 5- $\mathrm{HT}_{1 \mathrm{~B}}$ receptors in the regulation of paradoxical sleep as evidenced in $5-\mathrm{HT}_{1 \mathrm{~B}}$ knock-out mice. J Neurosci 19:3204-3212.

Boutrel B, Monaca C, Hen R, Hamon M, Adrien J (2002) Involvement of $5-\mathrm{HT}_{1 \mathrm{~A}}$ receptors in homeostatic and stress-induced adaptive regulations of paradoxical sleep: studies in $5-\mathrm{HT}_{1 \mathrm{~A}}$ knock-out mice. J Neurosci 22:4686-4692.

Casper RC, Fleisher BE, Lee-Ancajas JC, Gilles A, Gaylor E, DeBattista A, Hoyme HE (2003) Follow-up of children of depressed mothers exposed or not exposed to antidepressant drugs during pregnancy. J Pediatr 142:402-408.

Celada P, Puig M, Amargos-Bosch M, Adell A, Artigas F (2004) The therapeutic role of $5-\mathrm{HT}_{1 \mathrm{~A}}$ and $5-\mathrm{HT}_{2 \mathrm{~A}}$ receptors in depression. J Psychiatry Neurosci 29:252-265.

Dailly E, Chenu F, Petit-Demouliere B, Bourin M (2006) Specificity and efficacy of noradrenaline, serotonin depletion in discrete brain areas of Swiss mice by neurotoxins. J Neurosci Methods 150:111-115.

Daval G, Vergé D, Becerril A, Gozlan H, Spampinato U, Hamon M (1987) Transient expression of $5-\mathrm{HT}_{1 \mathrm{~A}}$ receptor binding sites in some areas of the rat CNS during postnatal development. Int J Dev Neurosci 5:171-180.

El Yacoubi M, Bouali S, Popa D, Naudon L, Leroux-Nicollet I, Hamon M, Costentin J, Adrien J, Vaugeois JM (2003) Behavioral, neurochemical, and electrophysiological characterization of a genetic mouse model of depression. Proc Natl Acad Sci USA 100:6227-6232.

Evrard A, Laporte AM, Chastanet M, Hen R, Hamon M, Adrien J (1999) $5-\mathrm{HT}_{1 \mathrm{~A}}$ and $5-\mathrm{HT}_{1 \mathrm{~B}}$ receptors control the firing of serotoninergic neurons in the dorsal raphe nucleus of the mouse: studies in $5-\mathrm{HT}_{1 \mathrm{~B}}$ knockout mice. Eur J Neurosci 11:3823-3831.

Fabre V, Beaufour C, Evrard A, Rioux A, Hanoun N, Lesch KP, Murphy DL, Lanfumey L, Hamon M, Martres MP (2000a) Altered expression and functions of serotonin 5- $\mathrm{HT}_{1 \mathrm{~A}}$ and 5- $\mathrm{HT}_{1 \mathrm{~B}}$ receptors in knock-out mice lacking the 5-HT transporter. Eur J Neurosci 12:2299-2310.

Fabre V, Boutrel B, Hanoun N, Lanfumey L, Fattaccini CM, Demeneix B, Adrien J, Hamon M, Martres MP (2000b) Homeostatic regulation of serotonergic function by the serotonin transporter as revealed by nonviral gene transfer. J Neurosci 20:5065-5075.

Feng P, Ma Y, Vogel GW (2001) The critical window of brain development from susceptive to insusceptive. Effects of clomipramine neonatal treatment on sexual behavior. Brain Res Dev Brain Res 129:107-110.

Fletcher A, Forster EA, Bill DJ, Brown G, Cliffe IA, Hartley JE, Jones DE, McLenachan A, Stanhope KJ, Critchley DJ, Childs KJ, Middlefell VC, Lanfumey L, Corradetti R, Laporte AM, Gozlan H, Hamon M, Dourish CT (1996) Electrophysiological, biochemical, neurohormonal and behavioural studies with WAY-100635, a potent, selective and silent $5-\mathrm{HT}_{1 \mathrm{~A}}$ receptor antagonist. Behav Brain Res 73:337-353.
Frank MG, Heller HC (1997) Neonatal treatments with the serotonin uptake inhibitors clomipramine and zimelidine, but not the noradrenaline uptake inhibitor desipramine, disrupt sleep patterns in adult rats. Brain Res 768:287-293.

Franklin KB, Paxinos G (1997) The mouse brain in stereotaxic coordinates, Ed 11. San Diego: Academic.

Fricker AD, Rios C, Devi LA, Gomes I (2005) Serotonin receptor activation leads to neurite outgrowth and neuronal survival. Brain Res Mol Brain Res 138:228-235.

Gaspar P, Cases O, Maroteaux L (2003) The developmental role of serotonin: news from mouse molecular genetics. Nat Rev Neurosci 4:1002-1012.

Gobbi G, Murphy DL, Lesch K, Blier P (2001) Modifications of the serotonergic system in mice lacking serotonin transporters: an in vivo electrophysiological study. J Pharmacol Exp Ther 296:987-995.

Gross C, Hen R (2004) The developmental origins of anxiety. Nat Rev Neurosci 5:545-552.

Gross C, Zhuang X, Stark K, Ramboz S, Oosting R, Kirby L, Santarelli L, Beck S, Hen R (2002) Serotonin1A receptor acts during development to establish normal anxiety-like behaviour in the adult. Nature 416:396-400.

Hansen HH, Mikkelsen JD (1998) Long-term effects on serotonin transporter mRNA expression of chronic neonatal exposure to a serotonin reuptake inhibitor. Eur J Pharmacol 352:307-315.

Holmes A, Yang RJ, Murphy DL, Crawley JN (2002) Evaluation of antidepressant-related behavioral responses in mice lacking the serotonin transporter. Neuropsychopharmacology 27:914-923.

Holmes A, Murphy DL, Crawley JN (2003) Abnormal behavioral phenotypes of serotonin transporter knockout mice: parallels with human anxiety and depression. Biol Psychiatry 54:953-959.

Holmes A, Le Guisquet AM, Vogel E, Millstein RA, Leman S, Belzung C (2005) Early life genetic, epigenetic and environmental factors shaping emotionality in rodents. Neurosci Biobehav Rev 29:1335-1346.

Horner RL, Sanford LD, Annis D, Pack AI, Morrison AR (1997) Serotonin at the laterodorsal tegmental nucleus suppresses rapid-eye-movement sleep in freely behaving rats. J Neurosci 17:7541-7552.

Kobayashi T, Homma Y, Good C, Skinner RD, Garcia-Rill E (2003) Developmental changes in the effects of serotonin on neurons in the region of the pedunculopontine nucleus. Brain Res Dev Brain Res 140:57-66.

Koe B, Weissman A (1966) p-Chlorophenylalanine: a specific depletor of brain serotonin. J Pharmacol Exp Ther 154:499-516.

Lauder JM (1990) Ontogeny of the serotonergic system in the rat: serotonin as a developmental signal. Ann NY Acad Sci 600:297-313; discussion 314.

Lena C, Popa D, Grailhe R, Escourrou P, Changeux JP, Adrien J (2004) $\beta 2$-containing nicotinic receptors contribute to the organization of sleep and regulate putative micro-arousals in mice. J Neurosci 24:5711-5718.

Li Q, Wichems C, Heils A, Van de Kar LD, Lesch KP, Murphy DL (1999) Reduction of 5-hydroxytryptamine (5-HT)(1A)-mediated temperature and neuroendocrine responses and 5-HT(1A) binding sites in 5-HT transporter knockout mice. J Pharmacol Exp Ther 291:999-1007.

Li Q, Wichems C, Heils A, Lesch KP, Murphy DL (2000) Reduction in the density and expression, but not G-protein coupling, of serotonin receptors $\left(5-\mathrm{HT}_{1 \mathrm{~A}}\right)$ in 5 -HT transporter knock-out mice: gender and brain region differences. J Neurosci 20:7888-7895.

Limoge-Lendais I, Robert C, Degrange M, Goldberg M, Stinus L, Limoge A (1994) Study on superbond adhesion to the skull for chronic electrode implantation in the rat. Neurosci Protocol 70:1-11.

Lira A, Zhou M, Castanon N, Ansorge MS, Gordon JA, Francis JH, BradleyMoore M, Lira J, Underwood MD, Arango V, Kung HF, Hofer MA, Hen R, Gingrich JA (2003) Altered depression-related behaviors and functional changes in the dorsal raphe nucleus of serotonin transporterdeficient mice. Biol Psychiatry 54:960-971.

Livak KJ, Schmittgen TD (2001) Analysis of relative gene expression data using real-time quantitative PCR and the 2(-Delta Delta C(T)) Method. Methods 25:402-408.

Maciag D, Simpson KL, Coppinger D, Lu Y, Wang Y, Lin RC, Paul IA (2005) Neonatal antidepressant exposure has lasting effects on behavior and serotonin circuitry. Neuropsychopharmacology 7:1-11.

Martin KF, Phillips I, Hearson M, Prow MR, Heal DJ (1992) Characterization of 8-OH-DPAT-induced hypothermia in mice as a $5-\mathrm{HT}_{1 \mathrm{~A}}$ autoreceptor response and its evaluation as a model to selectively identify antidepressants. Br J Pharmacol 107:15-21.

Martin P, Beninger RJ, Hamon M, Puech AJ (1990) Antidepressant-like ac- 
tion of 8-OH-DPAT, a 5- $\mathrm{HT}_{1 \mathrm{~A}}$ agonist, in the learned helplessness paradigm: evidence for a postsynaptic mechanism. Behav Brain Res 38:135-144.

Mathews TA, Fedele DE, Coppelli FM, Avila AM, Murphy DL, Andrews AM (2004) Gene dose-dependent alterations in extraneuronal serotonin but not dopamine in mice with reduced serotonin transporter expression. J Neurosci Methods 140:169-181.

Maudhuit C, Hamon M, Adrien J (1995) Electrophysiological activity of raphe dorsalis serotoninergic neurones in a possible model of endogenous depression. NeuroReport 6:681-684.

Monaca C, Boutrel B, Hen R, Hamon M, Adrien J (2003) 5- $\mathrm{HT}_{1 \mathrm{~A} / 1 \mathrm{~B}}$ receptor-mediated effects of the selective serotonin reuptake inhibitor, citalopram, on sleep: studies in 5- $\mathrm{HT}_{1 \mathrm{~A}}$ and 5- $\mathrm{HT}_{1 \mathrm{~B}}$ knockout mice. Neuropsychopharmacology 28:850-856.

Morrison JL, Riggs KW, Rurak DW (2005) Fluoxetine during pregnancy: impact on fetal development. Reprod Fertil Dev 17:641-650.

Muraki Y, Yamanaka A, Tsujino N, Kilduff TS, Goto K, Sakurai T (2004) Serotonergic regulation of the orexin/hypocretin neurons through the 5- $\mathrm{HT}_{1 \mathrm{~A}}$ receptor. J Neurosci 24:7159-7166.

Naudon L, El Yacoubi M, Vaugeois JM, Leroux-Nicollet I, Costentin J (2002) A chronic treatment with fluoxetine decreases 5-HT(1A) receptors labeling in mice selected as a genetic model of helplessness. Brain Res 936:68-75

Ninomiya Y, Kayama Y, Koyama Y (2005) Postnatal development of cholinergic neurons in the mesopontine tegmentum revealed by histochemistry. Int J Dev Neurosci 23:711-721.

Nordeng H, Lindemann R, Perminov KV, Reikvam A (2001) Neonatal withdrawal syndrome after in utero exposure to selective serotonin reuptake inhibitors. Acta Paediatr 90:288-291.

Overstreet DH, Commissaris RC, De La Garza II R, File SE, Knapp DJ, Seiden LS (2003) Involvement of 5- $\mathrm{HT}_{1 \mathrm{~A}}$ receptors in animal tests of anxiety and depression: evidence from genetic models. Stress 6:101-110.

Owens MJ (2004) Selectivity of antidepressants: from the monoamine hypothesis of depression to the SSRI revolution and beyond. J Clin Psychiatry 65 [Suppl 4]:5-10.

Pace-Schott EF, Hobson JA (2002) The neurobiology of sleep: genetics, cellular physiology and subcortical networks. Nat Rev Neurosci 3:591-605.
Patel TD, Zhou FC (2005) Ontogeny of 5- $\mathrm{HT}_{1 \mathrm{~A}}$ receptor expression in the developing hippocampus. Brain Res Dev Brain Res 157:42-57.

Pineyro G, Blier P (1999) Autoregulation of serotonin neurons: role in antidepressant drug action. Pharmacol Rev 51:533-591.

Popa D, El Yacoubi M, Vaugeois JM, Hamon M, Adrien J (2006) Homeostatic regulation of sleep in a genetic model of depression in the mouse: effects of muscarinic and 5-HT(1A) receptor activation. Neuropsychopharmacology, in press.

Raymond JR, Mukhin YV, Gettys TW, Garnovskaya MN (1999) The recombinant 5- $\mathrm{HT}_{1 \mathrm{~A}}$ receptor: $\mathrm{G}$ protein coupling and signalling pathways. Br J Pharmacol 127:1751-1764.

Sanz EJ, De-las-Cuevas C, Kiuru A, Bate A, Edwards R (2005) Selective serotonin reuptake inhibitors in pregnant women and neonatal withdrawal syndrome: a database analysis. Lancet 365:482-487.

Schwierin B, Borbely AA, Tobler I (1998) Sleep homeostasis in the female rat during the estrous cycle. Brain Res 811:96-104.

Serres F, Muma NA, Raap DK, Garcia F, Battaglia G, Van de Kar LD (2000) Coadministration of 5-hydroxytryptamine(1A) antagonist WAY-100635 prevents fluoxetine-induced desensitization of postsynaptic 5-hydroxytryptamine(1A) receptors in hypothalamus. J Pharmacol Exp Ther 294:296-301.

Tissier MH, Lainey E, Fattaccini CM, Hamon M, Adrien J (1993) Effects of ipsapirone, a 5- $\mathrm{HT}_{1 \mathrm{~A}}$ agonist, on sleep/wakefulness cycles: probable postsynaptic action. J Sleep Res 2:103-109.

Ursin R (2002) Serotonin and sleep. Sleep Med Rev 6:55-69.

Vogel G, Neill D, Hagler M, Kors D (1990) A new animal model of endogenous depression: a summary of present findings. Neurosci Biobehav Rev 14:85-91.

Wisor JP, Wurts SW, Hall FS, Lesch KP, Murphy DL, Uhl GR, Edgar DM (2003) Altered rapid eye movement sleep timing in serotonin transporter knockout mice. NeuroReport 14:233-238.

Xu Y, Sari Y, Zhou FC (2004) Selective serotonin reuptake inhibitor disrupts organization of thalamocortical somatosensory barrels during development. Brain Res Dev Brain Res 150:151-161.

Yan W, Wilson CC, Haring JH (1997) Effects of neonatal serotonin depletion on the development of rat dentate granule cells. Brain Res Dev Brain Res 98:177-184. 